\title{
The long-term phosphate experiment at Hamilton, Victoria
}

\author{
J.W.D. CAYLEY, G.R. SAUL and M.R. McCASKILL \\ Agriculture Victoria Hamilton, Pastoral and Veterinary Institute \\ Private Bag 105, Hamilton, Vic 3300, Australia
}

\begin{abstract}
At Hamilton, Victoria, the effects of grazing pressure and amount of single superphosphate (SSP) applied, on the productivity and soil resource status of grazing systems based on sheep, have been assessed since 1979. Early work showed that marginal and absolute responses in DM production to SSP were greater when assessed by measuring the net growth of grazed pastures compared with mowing, and that largest response occurred in spring. The botanical composition of the pasture has been dramatically influenced by the amount of SSP applied. Ryegrass and subterranean clover now constitute only $2.3 \%$ and $11.0 \%$ where an average of $1-4 \mathrm{~kg} \mathrm{P} / \mathrm{ha}$ has been applied each year. In addition, the digestibility of herbage from wellfertilised treatments was 4-9 units higher than from low-fertility treatments. The combination of these effects has allowed achievable annual gross margins to increase from $\$ 100 /$ ha at low-fertility treatments to about $\$ 400 /$ ha with $18 \mathrm{~kg} \mathrm{P} /$ ha applied annually. Indicators of sustainability show that so far there have been no major environmental consequences of applying SSP in amounts well above that used by district farmers.
\end{abstract}

Keywords: botanical composition, gross margin, pasture quality, phosphorus, sheep, sustainability

\section{Introduction}

At the Pastoral and Veterinary Institute, Hamilton, Victoria, an area was used to assess the response of pasture to single superphosphate (SSP) under mowing or grazing (Cayley \& Hannah 1995). This site has been used to study several aspects associated with applying SSP to pastures at a range of rates over many years. The regional climate is cool-temperate with a mean annual rainfall of $703 \mathrm{~mm}$. Long-term rainfall/evaporation for April-November and December-March is $555 / 588 \mathrm{~mm}$ and $148 / 728 \mathrm{~mm}$ respectively. Hamilton is an important area for wool production. This paper summarises the earlier studies, and presents results from the current programme.

\section{Background}

The pasture was sown in 1977 on an unfertilised area of basalt-derived duplex soil using perennial ryegrass, subterranean clover and phalaris, together with about 18 $\mathrm{kg} / \mathrm{ha}$ of phosphorus (P) applied as SSP. The available soil $\mathrm{P}$ (Olsen $\mathrm{P}$, sampled to $10 \mathrm{~cm}$ ) of unfertilised soil is about $4 \mu \mathrm{g} / \mathrm{g}$. A combination of 18 treatments was compared in a non-replicated factorial design comprising 6 levels of SSP, at each of which 3 stocking rates were used.

The site has been managed in 3 phases (Figure 1): a "build-up" phase (1979-1982) during which the comparison of grazing and mowing was made; a "rundown" phase (1985-1987) during which the plots were unfertilised, and comparisons of available soil $\mathrm{P}$ and a leaf tissue test conducted (Cayley et al. 1987); and a "maintenance phase" (1988 to present). The pastures were de-stocked for 6 months from December 1982 owing to drought. Measurements of pastures and sheep were discontinued during 1983 and 1984, as fences were destroyed by wildfire. Fertiliser was applied at 6 rates from 4-40 kg P/ha in 1984.

Figure 1 Cumulative application of $P$ at 6 levels.

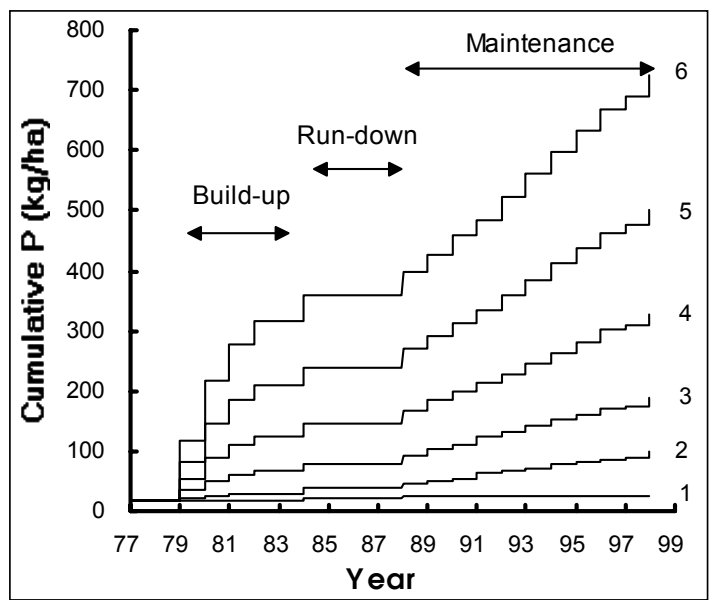

Up to 1986 , plots were each continuously stocked with 8 Corriedale hoggets at a low, medium or high stocking rate $(10,14$ or 18 sheep/ha), with new sheep 
used each year. The amount of $\mathrm{P}$ at the highest level of SSP during the build-up phase varied from $100 \mathrm{~kg} \mathrm{P} / \mathrm{ha} /$ year in the first 2 years to $40 \mathrm{~kg} \mathrm{P} / \mathrm{ha}$ in 1982. Plots were unfertilised at the lowest fertiliser level. By 1987, sheep grazing unfertilised plots even at all stocking rates were stressed (lower liveweights and poorer body condition), as the effectiveness of the initial applications of SSP diminished. It was also apparent that pasture grown on plots previously fertilised at the highest level was underutilised at the highest stocking rate. A change in the stocking policy was made in 1987 by varying the number of sheep per plot according to the level of SSP. This policy retained the varying stocking rates at each level of SSP, reduced the stress of sheep grazing plots at low levels of SSP, and enabled potential animal production per hectare at high levels of SSP to be estimated.

The assessment of the seasonal response to the fertiliser from 1979 to 1987 showed that the magnitude of the response to SSP was greatest in spring (Cayley et al. 1998), indicating that to efficiently utilise the pasture grown over a whole year, a production system with a larger demand for pasture in spring, such as springlambing ewes, would be appropriate. From lowest to highest amounts of SSP applied, the mean annual net pasture growth varied from 5.9 to $12.6 \mathrm{t} \mathrm{DM} / \mathrm{ha}$.

The experiment has been stocked with Septemberlambing, fine-wool merinos (fibre diameter $20 \mu \mathrm{m}$ ) since 1988. Amounts of $\mathrm{P} /$ ha corresponding to the 6 levels of SSP (Table 1) were chosen to maintain the P status of the soils at 6 levels, and the policy of varying sheep numbers per plot according to level of fertiliser was retained (Saul \& Cayley 1992). The small size of individual groups of sheep (4-10 animals per plot), and the need to avoid complications because of unequal lambing percentages, has necessitated the allocation of a new set of pregnant ewes to the plots each year. Ewes are maintained with $100 \%$ lambs at foot, and lambs are weaned at about 12 weeks of age and sold. After 12 months, the ewes are removed from the plots and shorn. The sheep receive a feed supplement (usually grain), if their body condition falls below a pre-determined level.

Table 1 Stocking rates (ewes/ha) of merino ewes and average $\mathrm{P}$ applied as fertilizer since 1977 .

\begin{tabular}{lcccccc}
\hline Grazing & \multicolumn{7}{c}{ Average fertiliser $\mathrm{P}$ applied (kg P/ha.year) --} \\
Pressure & 1 & 4 & 8 & 14 & 23 & 33 \\
\hline Low & 5.0 & 6.3 & 8.8 & 10.0 & 11.3 & 12.5 \\
Medium & 7.0 & 8.8 & 12.3 & 14.0 & 15.8 & 17.5 \\
High & 9.0 & 11.3 & 15.8 & 18.0 & 20.3 & 22.5 \\
\hline
\end{tabular}

\section{Effects of treatments on the pastures}

The comparison of the net growth of grazed and mown pastures showed that both the marginal and absolute responses to SSP were greater when assessed under grazing than under mowing (Cayley \& Hannah 1995).

An assessment of the botanical composition of the treatments (Table 2) shows that most of the variation has been owing to fertiliser. For the statistical analysis, $P$ rates 1 and 4, 8 and 14 and 23 and $33 \mathrm{~kg} \mathrm{P} /$ ha were combined. Onion grass (Romulea rosea), a low quality fibrous weed, disappeared at the high levels of $\mathrm{P}$ but constituted over $50 \%$ of the pasture at the lowest level of SPP. Browntop was also prevalent when soil fertility was low. Higher levels of SSP favoured ryegrass at low and medium grazing pressures, but when levels of SSP and grazing pressure were high, this species was displaced by volunteer legumes and broad-leaved weeds. Where the pasture is fertilised with $33 \mathrm{~kg} \mathrm{P} / \mathrm{ha} /$ year, and stocked at 22 ewes/ha, the proportion of perennial ryegrass has fallen steadily over the years. The proportion of other volunteer grasses such as barley grass, soft brome and Yorkshire fog showed no obvious trends with treatment.

Table 2 Botanical composition of pasture in October 1997.

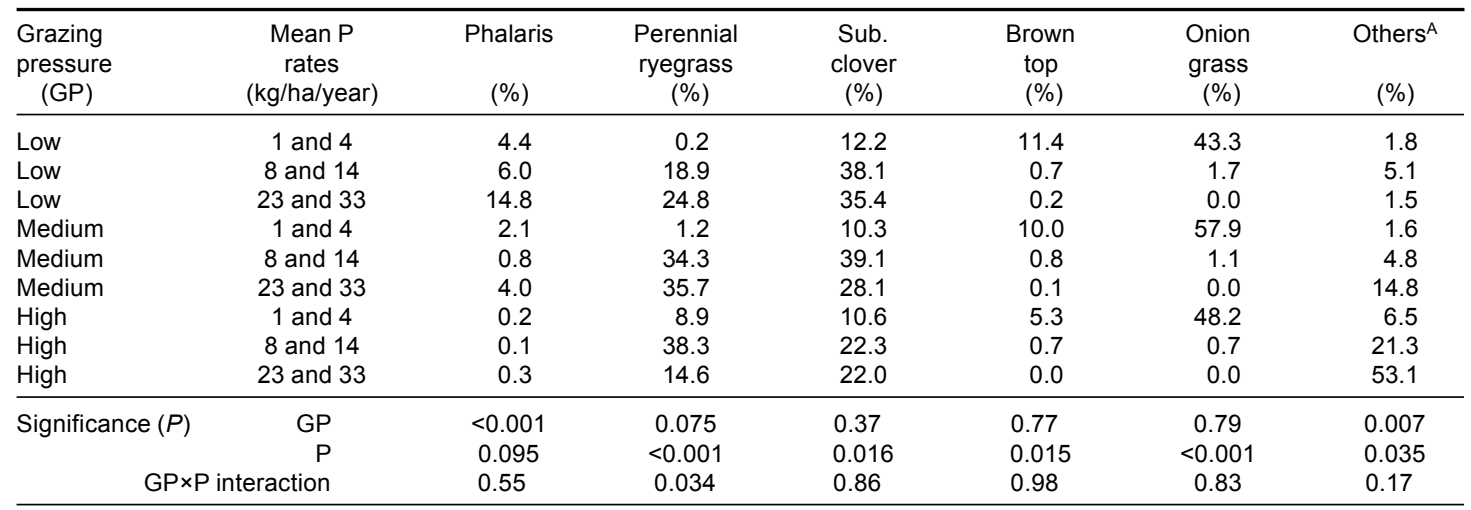

AOther 'High P'species: capeweed (Arctotheca calendula), storksbill (Erodium spp.), various annual legumes 
Fertiliser also improved the nutritive value of individual species. Measurements made from 1992-94 revealed that from the lowest to the highest rate of $P$, the crude protein content of subterranean clover was increased from $18 \%$ to $26 \%$, and the dry matter digestibility of subterranean clover, ryegrass and barley grass increased by 9,4 and 6 units, respectively.

\section{Production of merino ewes}

Multiple linear regression was used to model the key production variates of greasy fleece weight $(G F W, \mathrm{~kg})$, weaning weight of lambs (wean $W, \mathrm{~kg}$ ), and supplement fed (supp, MJ/ewe/year) by fitting terms derived from stocking rate $(S R$, ewes/ha) and mean $\mathrm{P}$ applied as SSP ( $\operatorname{avg} P, \mathrm{~kg} \mathrm{P} / \mathrm{ha} /$ year). The mean values for variates from 1988 to 1992 were used. A set of data from one year was used to derive the relationship between the fibre diameter of the wool $(D, \mu \mathrm{m})$ from GFW. The association between the price of wool $\left(P^{D}\right.$, cents $/ \mathrm{kg}$ greasy) at the predicted fibre diameter, and the value of $20 \mu \mathrm{m}$ wool $\left(P^{20}\right)$ was quantified for a set of data from wool sales provided by G. Lean (pers. comm.). Terms were included only if significant at the $5 \%$ level.

The regression models were:

1. $G F W=3.54-0.06 S R-0.060 \operatorname{avg} P+0.71 \sqrt{ } \operatorname{avg} P$

2. wean $W=24.6+0.60 S R-0.37 \operatorname{avg} P+3.85 \sqrt{ }$ avg $P-$ $5.58 \sqrt{ } S R$

3. for supp $\geq 0$, supp $=-600-54.7 S R+23.6$ avgP $224 \sqrt{ } \operatorname{avg} P+510 \sqrt{ } S R$

4. $D=17.2+0.87 G F W$

5. $P^{D}=12197+4.94 P^{20}+688 D-5810 \sqrt{ } D-0.1945 D P^{20}$

A computer spreadsheet incorporating these models was developed in order to predict the profitability of various combinations of avgP, SR, value of wool and lambs and variable costs (sheep, supplement and fertiliser). An example of the output from this model (Figure 2) shows that to fully derive the benefits associated with improved, well-fertilised pastures, SR must be increased.

\section{Indicators of sustainability}

Some attempt has been made to assess indicators of soil resource status for the various systems. There has been no effect of treatment on the diversity of earthworm species or their abundance (Baker et al. 1993). An audit of soil nutrients conducted in 1994 (McCaskill 1997) revealed that at the highest rate of SSP, $92.3 \%$ of applied $\mathrm{P}$, but only $32 \%$ of the applied sulphur (S) in the top 43 $\mathrm{cm}$ of soil could be accounted for in terms of nutrients retained, exported as product, and lost in run-off. The $\mathrm{P}$
Figure 2 Effect of stocking rate and $\mathrm{P}$ on gross margins. Assumed costs and prices: SSP $\$ 200 /$ tonne; oats $\$ 150$ /tonne, ewes $\$ 6.50 /$ head/year, lambs $\$ 0.75 / \mathrm{kg}$ liveweight and greasy 20 $\mu \mathrm{m}$ wool $\$ 4.00 / \mathrm{kg}$ (Arrows denote $98 \%$ of maximum predicted gross margin).

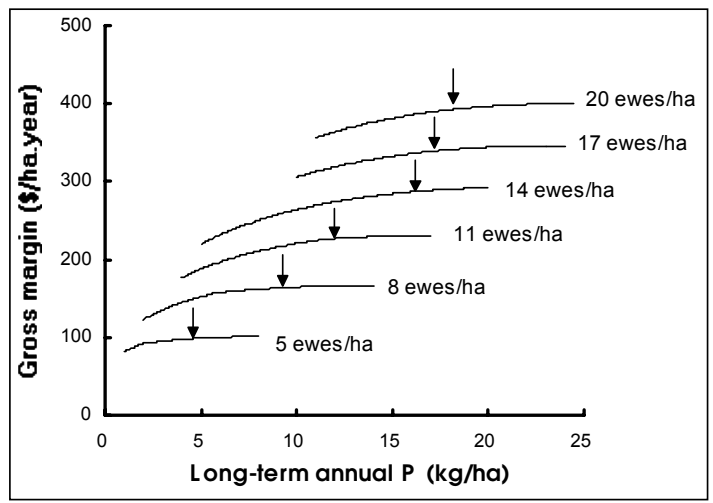

lost in run-off was estimated to be $\leq 0.3 \%$. The proportion of $\mathrm{P}$ and $\mathrm{S}$ retained increased at lower rates of SSP. The exchangeable magnesium in the topsoil was reduced from $326 \mathrm{mg} / \mathrm{kg}$ to $230 \mathrm{mg} / \mathrm{kg}$ at annual $\mathrm{P}$ rates of 1 to $33 \mathrm{~kg} / \mathrm{ha}$. There are no differences in the $\mathrm{pH}$ of the topsoil $(10 \mathrm{~cm}$ deep cores) between treatments.

\section{Conclusions}

Increased soil fertility combined with higher stocking rates and productive animal systems are the main way for livestock systems in the high rainfall zone of southern Australia to remain profitable. Results from this experiment provide a basis for understanding effects on soil, pastures and animals, and have been validated through a network of on-farm trials (de Fegely 1997). They provide a focus of a coordinated extension project throughout the region.

\section{ACKNOWLEDGEMENTS}

Thanks are extended to colleagues past and present at the Pastoral and Veterinary Institute who have contributed to this work. Financial support was provided by Australian wool growers and the Australian Government through the Australian Wool Research and Promotion Organisation, and also by the Victorial Government's Agriculture and Food Initiative.

\section{REFERENCES}

Baker, G.H.; Barrett, V.J.; Carter, P.J.; Cayley, J.W.D.; Saul, G.R. 1993. The influence of phosphate application and stocking rate on the abundance of earthworms in a Victorian pasture. pp. 85-91. In: 
Proceedings of the $6^{\text {th }}$ Australasian grassland invertebrate ecology conference. Prestidge, R.A. (ed.) AgResearch, Hamilton, New Zealand.

Cayley, J.W.D.; Cumming, K.N.; Flinn, P.C. 1987. Comparison of soil with leaf analysis for predicting the response of pasture to superphosphate. p. 249. In: Proceedings of the $4^{\text {th }}$ Australian agronomy conference. Reeves, T.G. (ed.) Australian Society of Agronomy, Melbourne.

Cayley, J.W.D.; Hannah, M.C. 1995. Response to phosphorus fertilizer compared under grazing and mowing. Australian journal of agricultural research 46: 1601-1619.

Cayley, J.W.D.; Hannah, M.C.; Kearney, G.A.; Clark, S.G. 1998. Effects of phosphorus fertiliser and rate of stocking on the seasonal pasture production of perennial ryegrass-subterranean clover pasture.
Australian journal of agricultural research 49: 233248.

de Fegly, C.R. 1979. Grassland's Productivity Program 1993-1997. Proceedings of the $38^{\text {th }}$ annual conference of the Grassland Society of Victoria: 111115.

McCaskill, M.R. 1997. Where is the P? Proceedings of the $38^{\text {th }}$ annual conference of the Grassland Society of Victoria: 55-60.

Saul, G.R.; Cayley, J.W.D. 1992. Appropriate animal stocking regimes for pasture comparisons. Proceedings of the Australian Society of Animal Production 19: 235. 